\title{
ADAPTATION ABILITIES AND QUALITY PARAMETERS OF SELECTED SOYBEAN LINES UNDER DOUBLE CROPPING IN THE MEDITERRANEAN REGION
}

\author{
Emre ILKER ${ }^{*}$, Mehmet KOCATURK ${ }^{2}$, Abdullah KADIROGLU ${ }^{2}$, Aliye YILDIRIM ${ }^{1}$, \\ Gulsum OZTURK ${ }^{1}$, Hakan YILDIZ ${ }^{1}$, Ibrahim KOKEN ${ }^{l}$ \\ ${ }^{1}$ Ege University, Faculty of Agriculture, Department of Field Crops, Izmir, TURKEY \\ ${ }^{2}$ Western Mediterranean Agricultural Research Institute, Antalya, TURKEY \\ *Corresponding author: emre.ilker@ege.edu.tr
}

Received: 31.01.2018

\begin{abstract}
The objective of this study was to determine the adaptation abilities and quality parameters of selected advanced soybean breeding lines at the double cropped growing conditions. 20 advanced Soybean [Glycine $\max \left(\mathrm{L}\right.$.) Merr] breeding lines $\left(\mathrm{F}_{7}\right)$ and four soybean varieties having maturity group III and IV (ARISOY, ATAEM-7, BRAVO and NOVA) were used. The differences between the lines and varieties were significant for the grain yield. The mean grain yield of breeding lines and varieties ranged from 2460 to $3488 \mathrm{~kg} \mathrm{ha}^{-1}$ and from 2933 to $3440 \mathrm{~kg} \mathrm{ha}^{-1}$, respectively. Also KA-07-05-13 advanced soybean line had the highest grain yield in terms of two years' average. The highest plant height was obtained from KA-07-08-15 $(82.2 \mathrm{~cm})$ and the lowest pod height from KA-07-08-15 $(12.2 \mathrm{~cm})$ and BDNA-19 $(12.1 \mathrm{~cm})$ lines. Significant differences were determined for pod number per plant among the 24 soybean genotypes. The pod number per plant was the higher in BDNA-12 and BDNA-13 lines than the varieties. In this research, the number of day for flowering varied between 33.0-42.1 days and the number of days for maturating ranged from 102.4 to 113.6 days. The earliest flowering time was detected from KA-07-08-14 line and the earliest maturating time was observed from BDNE-14 line. In a two-year average, 100-seed weight ranged between $14.2-20.8 \mathrm{~g}$ in breeding lines. The highest 100-seed weight was obtained from KA-07-03-5 $(20.8 \mathrm{~g})$ and KA-07-03-9 lines $(20.1 \mathrm{~g})$. While the highest oil percentage was obtained from ARISOY, the highest and statistically same oil percentage was recorded from KA-07-05-9 $(21,6 \%)$, KA-07-08-12 $(21,2 \%)$ and KA-07-05-5 $(21,2 \%)$. The average protein content of soybean lines and cultivars varied from $41.6 \%$ to $49.3 \%$. The higher protein percentage value was obtained from the BDAF-4 (49.3\%) breeding line.
\end{abstract}

Keywords: Agronomical characters, Oil percentage, Protein percentage, Soybean lines

\section{INTRODUCTION}

Soybean is one of the most valuable plants produced in the world, not only as a source of nutrition for the oily plant and for the fattening-fishery sector, but also as a source of protein for human nutrition and raw material for biofuel production. Soybean seed contains 18-24\% oil, $26 \%$ carbohydrates, $8 \%$ mineral matter and $36-45 \%$ protein percentage (Arioglu, 2014). Since its rich content in minerals and vitamins, it is a very valuable industrial plant for use in production of over 400 industrial products (Yildirim, 2017).

Double cropping is simply growing and harvesting two crops in one year. Compared to full season (main and double cropping) soybean production, grain yield reduction is a major concern in double-cropped soybean production systems (Boerma and Ashley, 1982; Board and
Hall, 1984; Kane et al., 1997; Arslan et al., 2006; Caliskan et al., 2007). Also while higher oil percentage results in

early planting, higher protein content is expected in late planting (Bellaloui et al., 2015). Caliskan et al. (2007) reported that in a wheat-soybean double-cropping system, grain yield could be increased by cultivar selection and suitable cultural practices. Indeed, Gulluoglu et al. (2016) and Ilker (2017) notified that soybean can be grown as a double-cropped after a small grain harvest in Mediterranean climate conditions. Besides, it has been well known that double cropping systems have very benefits such as increasing the profit, improving soil quality and reducing erosion, providing for a more intensive use of land, equipment, labor and capital also of course getting more production from the unit area.

Aim of this research was to develop good quality and high yielding new soybean varieties suitable for the 
double crop production, which is a very important product in closing the national oil opening and meeting the raw material requirement of the feed industry.

\section{MATERIALS AND METHOD}

Twenty advanced $\left(\mathrm{F}_{7}\right)$ soybean [Glycine $\max (\mathrm{L}$.) Merr] lines selected from $\mathrm{F}_{5}$ field trial conducted based on augmented design in Bornova-Izmir 2014 and four registered soybean varieties having maturity group III and IV (ARISOY, ATAEM7, BRAVO and NOVA) were evaluated in two trials laid out in 2015 June 24 and 2016
June 24 double crop growing seasons after wheat at Bornova-Izmir. Bornova is located (Latitude $38^{\circ} 28^{\prime}$ and Longitude $27^{\circ} 13^{\prime}$ ) in the west part of Turkey near Aegean Sea with altitude of $27 \mathrm{~m}$ and dominated by the Mediterranean climatic conditions. The climate data during the 2015-2016 growing period in experimental area were presented in Table 2. The experimental area has a heavy soil structure with clay-silt soil at $0-20 \mathrm{~cm}$ depth and clay-loamy structure at $20-40 \mathrm{~cm}$ depth. The soil test indicated a $\mathrm{p}^{\mathrm{H}}$ of 7.63 with $1688 \mathrm{~kg} \mathrm{ha}^{-1}$ of $\mathrm{K}_{2} \mathrm{O}$ and 7.40 $\mathrm{kg} \mathrm{ha}^{-1}$ of $\mathrm{P}_{2} \mathrm{O}_{5}$. In addition, the organic matter content of the soil was very low $(1.52 \%)$ and the lime content was $7.60 \%$.

Table 1. Advanced Soybean Lines and Registered Varieties Studied

\begin{tabular}{lccc}
\hline Line Codes & Pedigree & Line Codes & Pedigree \\
\hline BDMB-5 & Macon x Bert & KA-07-05-5 & NE 3399 x Bert \\
BDNA-19 & NE 3399x Apollo & KA-07-03-9 & HP 203 x Bert \\
BDNA-20 & NE 3399x Apollo & KA-07-08-12 & ATAEM-7 x Felix \\
BDNA-7 & NE 3399x Apollo & KA-07-05-9 & NE 3399 x Bert \\
BDNA-12 & NE 3399x Apollo & KA-07-05-2 & NE 3399 x Bert \\
BDNE-14 & 2 NE 3297 x Erie & KA-07-03-5 & HP 203 x Bert \\
BDNA-1 & NE 3399x Apollo & KA-07-08-14 & NE 3399 x Bert \\
BDNA-8 & NE 3399x Apollo & KA-07-08-15 & ATAEM-7 x Felix \\
BDNA-13 & NE 3399x Apollo & KA-07-08-9 & ATAEM-7 x Felix \\
BDAF-4 & Ataem 7 x Felix & KA-07-05-13 & NE 3399 x Bert \\
& Registered varieties: ARISOY, ATAEM-7, BRAVO and NOVA & \\
\hline
\end{tabular}

Table 2. The climatical data during the 2015-2016 growing period in experimental area (Anonymous, 2016)

\begin{tabular}{llccccc}
\hline & \multicolumn{2}{c}{ Average temp. $\left({ }^{\mathbf{0}} \mathbf{C}\right)$} & \multicolumn{2}{c}{ Relative humidity (\%) } & \multicolumn{2}{c}{ Precipitation (mm) } \\
Months/Years & $\mathbf{2 0 1 5}$ & $\mathbf{2 0 1 6}$ & $\mathbf{2 0 1 5}$ & $\mathbf{2 0 1 6}$ & $\mathbf{2 0 1 5}$ & $\mathbf{2 0 1 6}$ \\
\hline June & 24.6 & 27.5 & 52.2 & 47.9 & 30.9 & 2.8 \\
July & 28.7 & 29.3 & 47.7 & 44.5 & 0.2 & 0 \\
August & 29.3 & 28.9 & 54 & 51 & 1 & 0.4 \\
September & 26.4 & 24.7 & 55.5 & 50.1 & 12.9 & 8.6 \\
October & 19.7 & 19.4 & 63.2 & 57.7 & 48.1 & 0.5 \\
\hline
\end{tabular}

The trials were conducted as a randomized complete block design with four replications. Each plots consisted of 4 rows and $5 \mathrm{~m}$ long. The seeds, inoculated with Bradyrhizobium japonicum bacteria, were sown by hand as taking place 45 plants per square meter. Before planting, $200 \mathrm{~kg} \mathrm{ha}^{-1}$ of DAP $\left(36 \mathrm{~kg} \mathrm{ha}^{-1} \mathrm{~N}, 92 \mathrm{~kg} \mathrm{ha}^{-1} \mathrm{P}\right)$ fertilizers were applied in both growing seasons. Sprinkler irrigation was performed 6 times starting with sowing time in both years. For each plot, the harvest was performed on the date when the harvest maturity was observed. Observations and measurements were done for seven agronomical characters (grain yield, plant height, the lowest height, pods per plant, days for flowering, days for maturity, 100-seed weight) from the center rows of the each plot. Furthermore, approximately 150 grams of unground sample taken from each plot was filled into the natural vessel of Foss 6500 NIR without grinding and thenoil and protein ratios also oil yield $\mathrm{kg} \mathrm{ha}^{-1}$ were estimated from the reflectance spectrum values obtained from the 800-2500 $\mathrm{nm}$ wavelength range using the IC0923FE coded calibration program.

Analysis of variance across two years was calculated for each traits and LSD (least significant difference) test was applied to compare the differences (Steel and Torrie, 1980).

\section{RESULTS AND DISCUSSION}

Results from the analysis of variance for all traits demonstrated that differences among mean values for both genotypes and growing years (environments) were significant. Besides, significant genotype $\mathrm{x}$ year interactions for all traits indicated that differences among average values of genotypes were affected differently for two years (Table 3). 
Table 3. Mean squares for grain yield (GY), plant height (PH), Lowest pod height (LPH), pods per plant (PPP), days for flowering (DFF), days for maturity (DFM), 100-seed weight (HKW), protein content (\%) (PRT) and oil content (\%) (OIL).

\begin{tabular}{lllllll}
\hline Source & Df & GY & PH & LPH & PPP & DFF \\
\hline Genotypes $(G)$ & 23 & $5463.81^{* *}$ & $188.75^{* *}$ & $21.64^{* *}$ & $536.15^{* *}$ & $57.62^{* *}$ \\
YxG & 23 & $8027.13^{* *}$ & $157.35^{* *}$ & $14.52^{* *}$ & $660.03^{* *}$ & $2.36^{* *}$ \\
Years (Y) & 1 & $922.43 \mathrm{~ns}$ & $8354.02^{* *}$ & $2211.84^{* *}$ & $50935.87^{* *}$ & $3.52 \mathrm{~ns}$ \\
Blocks & 3 & $2156.92 \mathrm{~ns}$ & $654.14^{* *}$ & $4.88^{* *}$ & $219.38^{*}$ & $7.64^{* *}$ \\
Error & 141 & 952.29 & 47.62 & 0.89 & 63.69 & 1.13 \\
\hline Source & Df & DFM & HSW & PRT & OIL & \\
\hline Genotypes $(G)$ & 23 & $72.57 * *$ & $1830.19^{* *}$ & $21.61^{* *}$ & $4.88^{* *}$ & \\
YxG & 23 & $8.28^{* *}$ & $342.11^{* *}$ & $19.42^{* *}$ & $2.99^{* *}$ & $3.24 \mathrm{~ns}$ \\
Years (Y) & 1 & $15.19^{* *}$ & $34249.70^{* *}$ & $28.99^{* *}$ & $3.15 \mathrm{~ns}$ & \\
Blocks & 3 & $9.45^{* *}$ & $2170.51^{* *}$ & $3.48 \mathrm{~ns}$ & 0.19 & \\
Error & 141 & 1.52 & 116.73 & 4.01 & 1.19 & \\
\hline
\end{tabular}

ns: none significant, $*$ significant at 0.05 level, $* *:$ significant at 0.01 level

Grain yield of lines and varieties varied from $2460-$ $3393 \mathrm{~kg} \mathrm{ha}^{-1}$ and 2933-3440 $\mathrm{kg} \mathrm{ha}^{-1}$ respectively (Table 4). The differences between the lines and varieties were statistically significant. Considering average grain yields of the genotypes over the two years, the highest grain yield was obtained from KA-07-05-13 advanced soybean line. However, this genotype showed lower performance in second year. BDMB-5 breeding line which had similar grain yield with the control varieties ATAEM-7 showed more reliable and stable performances in terms of data of the two years. It was indicated that genotypes of the present study are highly promising lines and shows superiority than those researchers' Gaffaroglu Yetkin and Arioglu (2009) who reported grain yield ranged from $1908 \mathrm{~kg} \mathrm{ha}^{-1}$ to $3146 \mathrm{~kg} \mathrm{ha}^{-1}$ in the main growing conditions in Cukurova region and Mariani et al. (2012) who reported soybean grain yield between $2482 \mathrm{~kg} \mathrm{ha}^{-1}$ and $2837 \mathrm{~kg} \mathrm{ha}^{-1}$ in northern Rio Grande do Sul State conditions On the other hand current results gave lower performance than the findings of Ilker (2017) and according to the results of Gulluoglu et al. (2016) who reported that soybean yield can reach $4000 \mathrm{~kg} \mathrm{ha}^{-1}$ and more in double cropping conditions at Adana province.

The maximum average plant height was obtained from the BDMB-5 line in the first year and from the KA-07-055 line in second year (Table 4). According to mean yield of the two years, the highest plant height was recorded from the advanced line KA-07-08-15 as $82.2 \mathrm{~cm}$. Besides, it was found that all the advanced soybean lines except for Ka-07-03-5 line were higher than registered cultivars. On the other hand, Tugay and Atikyilmaz (2009) reported higher plant height ranged from $90 \mathrm{~cm}$ to $148 \mathrm{~cm}$ in the main growing conditions in Izmir. Furthermore, Ilker (2017) reported positive correlations between plant height and long vegetation period and supported his findings with the results of Sousa et al. (2015) as well. Our results have also show parallelism with their determinations. First pod height (FPH) is an agronomic trait for the mechanical harvesting of soybeans with combines. According the mean values of the first pod height, the two years results can be clearly show that soybean advanced lines are superior genotypes than registered cultivars. The highest average first pod height was obtained in KA-07-08-15 $(12.2 \mathrm{~cm})$ and BDNA-19 $(12.1 \mathrm{~cm})$ whereas the lowest was in BDNA-13 line as 7,9 cm and BDAF-4 as $8,7 \mathrm{~cm}$ (Table 4). However, when the mean values of FPH over all genotypes and varieties were compared with those of other researchers (Unal and Onder, 2008; Gulluolgu et al., 2016; Kang et al., 2017), FPA has not reached the desired level. Pod number per plant and seed number per pod contribute to overall yield. The lowest pod height is an important plant parameter to reduce harvest loss, especially in wheat soybean double cropping systems (Caliskan et al., 2007). Since, pods too close to the soil surface increase harvest losses since some combine harvester heads are unable to pick up the lowest pods. 
Table 4. The means of soybean lines and varieties and LSD groups of grain yield, plant height, first pod height and pod number plant

\begin{tabular}{|c|c|c|c|c|c|c|c|c|c|c|c|c|}
\hline \multirow{3}{*}{ Genotypes (A) } & \multicolumn{3}{|c|}{ Grain yield $\left(\mathrm{kg} \mathrm{ha}^{-1}\right)$} & \multicolumn{3}{|c|}{ Plant height $(\mathbf{c m})$} & \multicolumn{3}{|c|}{ lowest pod height $(\mathrm{cm})$} & \multicolumn{3}{|c|}{ Pod number ( plant $^{-1}$ ) } \\
\hline & \multicolumn{3}{|l|}{ Years (B) } & \multicolumn{3}{|c|}{ Years (B) } & \multicolumn{3}{|c|}{ Years (B) } & \multicolumn{3}{|c|}{ Years (B) } \\
\hline & 2015 & 2016 & Mean & 2015 & 2016 & Mean & 2015 & 2016 & Mean & 2015 & 2016 & Mean \\
\hline BDMB-5 & $3583^{\mathrm{abc}}$ & $3203^{\mathrm{abcd}}$ & 3393 & $77.6^{\mathrm{a}}$ & $80.2^{\text {cdef }}$ & 78.9 & $6.6^{\text {cdef }}$ & $15.0^{\text {cdefg }}$ & 10.8 & $70.6^{\mathrm{de}}$ & $36.7^{\text {defgh }}$ & 53.6 \\
\hline BDNA-19 & $3903^{a}$ & $2536^{\mathrm{g}}$ & 3219 & $61.6^{\mathrm{def}}$ & $87.9^{\mathrm{abc}}$ & 74.7 & $6.2^{\mathrm{def}}$ & $18.0^{\mathrm{a}}$ & 12.1 & $76.8^{\mathrm{cd}}$ & $34.1^{\text {efgh }}$ & 55.4 \\
\hline BDNA-20 & $2725^{1 \mathrm{jk}}$ & $2992^{\mathrm{def}}$ & 2858 & $67.1^{\text {bcde }}$ & $81.3^{\text {cdef }}$ & 74.2 & $5.3^{\mathrm{fg}}$ & $13.1^{\mathrm{h} 1}$ & 9.2 & $82.4^{\mathrm{bc}}$ & $43.6^{\text {bcde }}$ & 63 \\
\hline BDNA-7 & $3207^{\text {cdefg }}$ & $1713^{\mathrm{h}}$ & 2460 & $68.6^{\mathrm{abcd}}$ & $84.3^{\text {abcdef }}$ & 76.4 & $6.0^{\text {defg }}$ & $14.7^{\text {defg }}$ & 10.3 & $73.6^{\mathrm{cd}}$ & $34.7^{\text {efgh }}$ & 54.2 \\
\hline BDNA-12 & $3284^{\text {cdef }}$ & $3156^{\mathrm{abcd}}$ & 3220 & $72.1^{\mathrm{abc}}$ & $80.3^{\text {cdef }}$ & 76.2 & $8.4^{\mathrm{ab}}$ & $12.1^{1 \mathrm{j}}$ & 10.2 & $107.0^{\mathrm{a}}$ & $36.0^{\text {efgh }}$ & 71.5 \\
\hline BDNE-14 & $2968^{\text {defghij }}$ & $3228^{\mathrm{abcd}}$ & 3098 & $74.9^{\mathrm{ab}}$ & $78.3^{\text {cdef }}$ & 76.6 & $7.0^{\text {cde }}$ & $11.9^{\mathrm{ij}}$ & 9.5 & $59.7^{\mathrm{ef}}$ & $35.9^{\text {efgh }}$ & 47.8 \\
\hline BDNA-1 & $3165^{\text {cdefgh }}$ & $2683^{\mathrm{efg}}$ & 2924 & $74.0^{\mathrm{ab}}$ & $77.8^{\mathrm{def}}$ & 75.9 & $6.4^{\mathrm{def}}$ & $17.4^{\mathrm{ab}}$ & 11.9 & $84.6^{\mathrm{bc}}$ & $36.6^{\text {defgh }}$ & 60.6 \\
\hline BDNA-8 & $2752^{\text {hijk }}$ & $3359^{\mathrm{abcd}}$ & 3056 & $74.4^{\mathrm{ab}}$ & $82.7^{\text {bcdef }}$ & 78.5 & $6.8^{\text {cde }}$ & $15.1^{\text {cdef }}$ & 10.9 & $59.5^{\mathrm{f}}$ & $37.8^{\text {cdefgh }}$ & 48.6 \\
\hline BDNA-13 & $2403^{\mathrm{k}}$ & $3239^{\mathrm{abcd}}$ & 2824 & $67.0^{\text {bcde }}$ & $75.9^{\mathrm{efg}}$ & 71.4 & $6.8^{\text {cde }}$ & $8.9^{\mathrm{kl}}$ & 7.9 & $75.3^{\mathrm{cd}}$ & $69.7 \mathrm{a}$ & 72.5 \\
\hline BDAF-4 & $2830^{\text {ghijk }}$ & $3402^{\mathrm{abcd}}$ & 3116 & $68.0^{\text {abcde }}$ & $78.7^{\text {cdef }}$ & 73.4 & $6.0^{\text {defg }}$ & $11.5^{\mathrm{j}}$ & 8.7 & $81.1^{\mathrm{bcd}}$ & $33.8^{\text {efgh }}$ & 57.5 \\
\hline KA-07-05-5 & $2857^{\text {fghij }}$ & $3355^{\mathrm{abcd}}$ & 3106 & $62.7^{\text {cdef }}$ & $93.7^{\mathrm{a}}$ & 78.2 & $6.1^{\text {defg }}$ & $15.3^{\text {cde }}$ & 10.7 & $56.1^{\mathrm{f}}$ & $48.5^{\mathrm{bc}}$ & 52.3 \\
\hline KA-07-03-9 & $3722^{\mathrm{ab}}$ & $3170^{\mathrm{abcd}}$ & 3446 & $58.5^{\text {ef }}$ & $75.2^{\mathrm{fg}}$ & 66.9 & $7.8^{\mathrm{abc}}$ & $15.3^{\text {cde }}$ & 1 & $82.9^{\mathrm{bc}}$ & $29.3^{\mathrm{gh}}$ & 56.1 \\
\hline KA-07-08-12 & $2979^{\text {defgh }} 1$ & $3158^{\mathrm{abcd}}$ & 3069 & $62.6^{\text {cdef }}$ & $85.2^{\text {abcde }}$ & 73.9 & $6.8^{\text {cde }}$ & $13.8^{\mathrm{fgh}}$ & 10.3 & $80.1^{\text {bcd }}$ & $36.9^{\text {defgh }}$ & 58.5 \\
\hline KA-07-05-9 & $2827^{\text {ghijk }}$ & $3400^{\mathrm{abcd}}$ & 3113 & $61.8^{\mathrm{def}}$ & $75.4^{\mathrm{fg}}$ & 68.6 & $7.0^{\text {cde }}$ & $14.3^{\text {defgh }}$ & 10.7 & $53.4^{\mathrm{f}}$ & $27.1^{\mathrm{h}}$ & 40.2 \\
\hline KA-07-05-2 & $2919^{\text {efghij }}$ & $3471^{\mathrm{ab}}$ & 3195 & $58.4^{\mathrm{ef}}$ & $76.7^{\text {efg }}$ & 67.5 & $7.0^{\text {cde }}$ & $15.3^{\text {cde }}$ & 11.2 & $88.6^{\mathrm{b}}$ & $47.2^{\mathrm{bcd}}$ & 67.9 \\
\hline KA-07-03-5 & $2806^{\mathrm{ghijk}}$ & $3062^{\text {bcde }}$ & 2934 & $60.1^{\text {def }}$ & $68.1^{\mathrm{g}}$ & 64.1 & $6.9^{\text {cde }}$ & $16.2^{\mathrm{bc}}$ & 11.5 & $91.0^{\mathrm{b}}$ & $29.0^{\mathrm{gh}}$ & 60 \\
\hline KA-07-08-14 & $3068^{\text {defgh } 1}$ & $3277^{\mathrm{abcd}}$ & 3172 & $66.3^{\text {bcde }}$ & $84.2^{\text {abcdef }}$ & 75.2 & $8.8^{\mathrm{a}}$ & $14.7^{\text {defg }}$ & 11.8 & $59.7^{\mathrm{ef}}$ & $34.9^{\text {efgh }}$ & 47.3 \\
\hline KA-07-08-15 & $3287^{\text {cdef }}$ & $2440^{\mathrm{g}}$ & 2863 & $72.1^{\mathrm{abc}}$ & $92.3^{\mathrm{ab}}$ & 82.2 & $8.9^{\mathrm{a}}$ & $15.5^{\mathrm{cd}}$ & 12.2 & $60.3^{\mathrm{ef}}$ & $51.5^{b}$ & 55.9 \\
\hline KA-07-08-9 & $2546^{\mathrm{jk}}$ & $2585^{\mathrm{fg}}$ & 2565 & $69.3^{\mathrm{abcd}}$ & $87.3^{\mathrm{abcd}}$ & 78.3 & $7.3^{\mathrm{bcd}}$ & $15.4^{\text {cde }}$ & 11.3 & $59.0^{\mathrm{f}}$ & $43.0^{\text {bcde }}$ & 51 \\
\hline KA-07-05-13 & $3959^{a}$ & $3017^{\text {cde }}$ & 3488 & $58.6^{\mathrm{ef}}$ & $83.3^{\text {cbdef }}$ & 71 & $6.9^{\text {cde }}$ & $13.7^{\mathrm{gh}}$ & 10.3 & $76.6^{\mathrm{cd}}$ & $41.0^{\text {bcdef }}$ & 58.8 \\
\hline ARISOY & $2721^{1 \mathrm{jk}}$ & $3146^{\mathrm{abcd}}$ & 2933 & $56.5^{\mathrm{f}}$ & $76.1^{\text {efg }}$ & 66.3 & $7.2^{\mathrm{bcd}}$ & $14.1^{\mathrm{efgh}}$ & 10.6 & $57.7^{\mathrm{f}}$ & $30.7^{\mathrm{fgh}}$ & 44.2 \\
\hline ATAEM 7 & $3362^{\text {bcd }}$ & $3497^{a}$ & 3430 & $71.4^{\mathrm{abc}}$ & $67.3^{\mathrm{g}}$ & 69.3 & $6.6^{\text {cdef }}$ & $7.8^{\mathrm{lm}}$ & 7.2 & $81.1^{\text {bcd }}$ & $39.5^{\text {cdefg }}$ & 60.3 \\
\hline BRAVO & $3348^{\text {bcde }}$ & $3427^{\mathrm{abc}}$ & 3388 & $69.0^{\mathrm{abcd}}$ & $68.0^{\mathrm{g}}$ & 68.5 & $4.8^{\mathrm{g}}$ & $7.0^{\mathrm{m}}$ & 5.9 & $61.3^{\mathrm{ef}}$ & $65.1^{\mathrm{a}}$ & 63.2 \\
\hline NOVA & $3365^{\text {bcd }}$ & $3022^{\text {cde }}$ & 3194 & $75.0^{\mathrm{ab}}$ & $83.5^{\text {bcdef }}$ & 79.3 & $5.8^{\mathrm{efg}}$ & $9.9^{\mathrm{k}}$ & 7.8 & $60.1^{\mathrm{ef}}$ & $33.9^{\text {efgh }}$ & 47 \\
\hline Mean & 3108 & 3064 & 3086 & 67.0 & 80.2 & 73.6 & 6.8 & 13.6 & 10.2 & 72.4 & 39.9 & 56.1 \\
\hline $\operatorname{LSD}\left(\% 1_{\mathrm{AxB}}\right)$ & 43 & & 30.50 & & & 6.81 & & 31 & 0.93 & & 14 & 7.87 \\
\hline
\end{tabular}

Significant differences were determined for pod number per plant (PPP) among the 24 soybean genotypes. Besides differences between the two years is also important. Especially in the second year, some of the genotypes were found to be seriously decreased in pod number. As a result of this, genotype $\mathrm{x}$ environment interaction was found significantly important. However real and strong effect for PPP could have come from the differences of the years. It has been understood that some advanced lines (BDNA12 , BDNA-13 etc.) have significantly more pod number than registered varieties (Table 4). Also our results are more desirable level than Bakal et al. (2017) who reported that the average pod number per plant was 48,2 pods per plant in the main growing conditions in Mediterranean climate zone.

Whigham and Minor (1978) reported that differences in day length result in responses in term of the number of days to flower, the number of days to maturity, plant height, seed weight, pod number, branch number and node number (Bakal et al., 2017). Soybean is a short-day crop and its development is largely determined by varietyspecific day length requirements that initiate floral development (Holshouser, 2010). Especially in the double crop conditions, the number of days for flowering and the number of days for maturity are important for earliness. In this research the number of day for flowering varied between 33.0 and 42.1 days and the number of days for maturating ranged from 102.4 to 113.6 days (Table 5). The earliest flowering time was detected from KA-07-08-
14 line and the earliest maturating time was observed from BDNE-14 line. Gulluoglu et al. (2011) obtained Flowering date between 22 to 45 days and maturating date between 85-129 days in the 2015 to 2016 growing season.

Variations in terms of 100-seed weights were found statistically significant. The 100-seed weight of soybean varieties and lines ranged from $12.8 \mathrm{~g}$ to $19.0 \mathrm{~g}$ in 2015 and varied between 15.6-22.6 g in 2016. The 2-year average 100-seed weight ranged between $14.2-20.8 \mathrm{~g}$ (Table 5). The 100-seed weight and pod number per plant traits are the most important seed yield components in soybean (Onat et al., 2017). The highest 100-seed weight was obtained from KA-07-03-5 (20.8 g) and KA-07-03-9 lines (20.1 g). Bakal et al. (2017) reported 16.7-19.0 g in main crop and 12.9-15.3 g 100-seed weight in double crop growing season. Our results are more promising than the researcher's findings for double crop conditions.

The average oil content of soybean genotypes ranged between $18-22 \%$ (Table 6). The highest oil percentage was detected from ARISOY and it was followed by KA07-05-9, KA-07-08-12 and KA-07-05-5. It was understood that our results are possibly better than Bakal et al. (2017) who reported the oil content values of soybean varieties ranged between $17.7-20.0 \%$ in main crop season and 17.1-19.4\% in double crop growing season in a two-year average. When the two-year average of the obtained oil content and grain yield values are jointly evaluated in current research, $718.5 \mathrm{~kg} \mathrm{ha}^{-1}$ of oil obtained from the KA-07-05-13 promising advanced line 
which was ranked in group "a" with ATAEM-7 for oil yield.

Table 5. The means of soybean lines and varieties and LSD groups of days of flowering, days of maturing and 100-seed weight

\begin{tabular}{|c|c|c|c|c|c|c|c|c|c|}
\hline \multirow{3}{*}{ Genotypes (A) } & \multirow{2}{*}{\multicolumn{3}{|c|}{$\begin{array}{c}\text { Days for flowering (DFF) } \\
\text { Years }(\mathbf{B})\end{array}$}} & \multicolumn{3}{|c|}{ Days for maturing (DFM) } & \multirow{2}{*}{\multicolumn{2}{|c|}{$\begin{array}{c}100 \text { seed weight }(\mathrm{g}) \\
\text { Years }(\mathrm{B})\end{array}$}} & \multirow[b]{3}{*}{ Mean } \\
\hline & & & & \multicolumn{3}{|c|}{ Years $(B)$} & & & \\
\hline & 2015 & 2016 & Mean & 2015 & 2016 & Mean & \multicolumn{2}{|c|}{$2015 \quad 2016$} & \\
\hline BDMB-5 & $42.0^{\mathrm{a}}$ & $39.5^{b}$ & 40.8 & $110.3^{c}$ & $108.0^{\text {defgh }}$ & 109.1 & $15.7^{\text {cdef }}$ & $16.7^{\text {ght }}$ & 16.2 \\
\hline BDNA-19 & $41.0^{\mathrm{ab}}$ & $39.0^{\mathrm{bc}}$ & 40 & $110.3^{c}$ & $109.0^{\text {cde }}$ & 109.6 & $14.7^{\text {efghı }}$ & $17.5^{\mathrm{fg}}$ & 16.1 \\
\hline BDNA-20 & $40.0^{\mathrm{bc}}$ & $37.5^{\mathrm{de}}$ & 38.8 & $109.8^{\mathrm{c}}$ & $107.3^{\text {fgh } 1}$ & 108.5 & $14.9^{\mathrm{efgh}}$ & $17.2^{\mathrm{gh}}$ & 16.1 \\
\hline BDNA-7 & $39.8^{\mathrm{bcd}}$ & $39.0^{\mathrm{bc}}$ & 39.4 & $107.8^{\mathrm{ef}}$ & $108.5^{\text {def }}$ & 108.1 & $15.1^{\mathrm{efgh}}$ & $17.3^{\mathrm{gh}}$ & 16.2 \\
\hline BDNA-12 & $40.8^{\mathrm{ab}}$ & $39.5^{\mathrm{b}}$ & 40.1 & $106.3^{\mathrm{fg}}$ & $109.0^{\text {cde }}$ & 107.6 & $15.7^{\text {cdef }}$ & $17.4^{\mathrm{fg}}$ & 16.6 \\
\hline BDNE-14 & $35.3^{1 \mathrm{j}}$ & $34.0^{\mathrm{h}}$ & 34.6 & $101.8^{\mathrm{j}}$ & $103.0^{\mathrm{m}}$ & 102.4 & $16.9^{\mathrm{bc}}$ & $18.8^{\mathrm{def}}$ & 17.9 \\
\hline BDNA-1 & $38.5^{\text {def }}$ & $37.8^{\mathrm{cd}}$ & 38.1 & $109.5^{\mathrm{cd}}$ & $109.5^{\mathrm{bcd}}$ & 109.5 & $13.9^{\text {hij }}$ & $17.2^{\mathrm{gh}}$ & 15.5 \\
\hline BDNA-8 & $37.5^{\mathrm{fg}}$ & $35.8^{f}$ & 36.6 & $112.3^{\mathrm{b}}$ & $109.5^{\mathrm{bcd}}$ & 110.9 & $16.9^{\mathrm{bc}}$ & $17.9^{\text {efg }}$ & 17.4 \\
\hline BDNA-13 & $37.0^{\mathrm{gh}}$ & $38.0^{\mathrm{cd}}$ & 37.5 & $103.3^{\mathrm{ij}}$ & $107.8^{\mathrm{efgh}}$ & 105.5 & $15.8^{\text {cdef }}$ & $17.9^{\mathrm{efg}}$ & 16.9 \\
\hline BDAF-4 & $35.8^{\mathrm{h}_{1}}$ & $36.0^{f}$ & 35.9 & $104.0^{1}$ & $104.8^{\mathrm{kl}}$ & 104.4 & $14.9^{\text {efgh }}$ & $15.8^{\mathrm{h} 1}$ & 15.3 \\
\hline KA-07-05-5 & $38.5^{\text {def }}$ & $37.8^{\mathrm{cd}}$ & 38.1 & $109.5^{\mathrm{cd}}$ & $110.5^{\mathrm{bc}}$ & 110 & $16.6^{\mathrm{bcd}}$ & $17.0^{\text {ght }}$ & 16.8 \\
\hline KA-07-03-9 & $41.0^{\mathrm{ab}}$ & $41.3^{\mathrm{a}}$ & 41.1 & $112.3^{\mathrm{b}}$ & $115.0^{\mathrm{a}}$ & 113.6 & $17.7^{\mathrm{ab}}$ & $22.4^{\mathrm{ab}}$ & 20.1 \\
\hline KA-07-08-12 & $35.5^{1}$ & $36.3^{\mathrm{ef}}$ & 35.9 & $108.0^{\mathrm{de}}$ & $105.8^{\mathrm{ijk}}$ & 106.9 & $14.2^{\text {ghij }}$ & $17.4^{\mathrm{fg}}$ & 15.8 \\
\hline KA-07-05-9 & $35.5^{1}$ & $35.5^{\mathrm{fg}}$ & 35.5 & $107.8^{\mathrm{ef}}$ & $106.5^{\mathrm{hij}}$ & 107.1 & $15.5^{\text {cdefg }}$ & $19.9^{\mathrm{cd}}$ & 17.7 \\
\hline KA-07-05-2 & $33.5^{\mathrm{kl}}$ & $33.8^{\mathrm{h}}$ & 33.6 & $108.0^{\mathrm{de}}$ & $104.5^{\mathrm{klm}}$ & 106.3 & $12.8^{j}$ & $15.6^{1}$ & 14.2 \\
\hline KA-07-03-5 & $41.8^{\mathrm{a}}$ & $42.5^{\mathrm{a}}$ & 42.1 & $115.8^{\mathrm{a}}$ & $114.8^{\mathrm{a}}$ & 115.3 & $19.0^{\mathrm{a}}$ & $22.6^{\mathrm{a}}$ & 20.8 \\
\hline KA-07-08-14 & $32.8^{\mathrm{kl}}$ & $33.3^{\mathrm{h}}$ & 33 & $107.5^{\text {ef }}$ & $103.8^{\mathrm{lm}}$ & 105.6 & $13.4^{\mathrm{j}}$ & $16.7^{\text {ghı }}$ & 15.0 \\
\hline KA-07-08-15 & $39.0^{\text {cde }}$ & $39.0^{\mathrm{bc}}$ & 39 & $112.5^{\mathrm{b}}$ & $111.0^{\mathrm{b}}$ & 111.8 & $15.5^{\text {cdefg }}$ & $17.3^{\mathrm{fg}}$ & 16.4 \\
\hline KA-07-08-9 & $35.5^{1}$ & $35.8^{f}$ & 35.6 & $109.5^{\mathrm{cd}}$ & $108.3^{\text {defg }}$ & 108.9 & $15.3^{\text {defgh }}$ & $17.8^{\mathrm{efg}}$ & 16.6 \\
\hline KA-07-05-13 & $38.3^{\mathrm{efg}}$ & $39.8^{b}$ & 39 & $110.0^{\mathrm{c}}$ & $109.5^{\mathrm{bcd}}$ & 109.8 & $15.9^{\text {cde }}$ & $19.3^{\mathrm{de}}$ & 17.6 \\
\hline ARISOY & $32.3^{1}$ & $33.3^{\mathrm{h}}$ & 32.8 & $107.0^{\text {efg }}$ & $105.3^{\mathrm{jkl}}$ & 106.1 & $14.3^{\text {fghij }}$ & $16.9^{\text {ghı }}$ & 15.6 \\
\hline ATAEM 7 & $34.0^{\mathrm{jk}}$ & $33.0^{\mathrm{h}}$ & 33.5 & $105.8^{\mathrm{gh}}$ & $104.3^{\mathrm{klm}}$ & 105 & $14.5^{\text {efght }}$ & $17.5^{\mathrm{fg}}$ & 16.0 \\
\hline BRAVO & $33.5^{\mathrm{kl}}$ & $34.3^{\mathrm{gh}}$ & 33.9 & $104.5^{\mathrm{h} 1}$ & $104.5^{\mathrm{klm}}$ & 104.5 & $13.43^{\mathrm{ij}}$ & $16.9^{\text {ght }}$ & 15.1 \\
\hline NOVA & $33.3^{\mathrm{kl}}$ & $34.0^{\mathrm{h}}$ & 33.6 & $107.0^{\text {efg }}$ & $106.8^{\text {ghij }}$ & 106.9 & $15.1^{\mathrm{efgh}}$ & $21.1^{\mathrm{bc}}$ & 18.1 \\
\hline Mean & 37.2 & 36.9 & 37.0 & 108.3 & 107.8 & 108.1 & 15.3 & 18.0 & 16.7 \\
\hline $\operatorname{LSD}\left(\% 1_{\mathrm{AxB}}\right)$ & 1.4 & & 1.05 & & & 1.22 & 1.5 & & 1.06 \\
\hline
\end{tabular}

The differences among the soybean genotypes were statistically significant for protein content. The mean protein content of soybean lines and registered cultivars varied from $41.6 \%$ to $49.3 \%$ (Table 6). The highest protein content obtained from BDAF-4 and it was followed by KA-07-03-5 (47.2\%) and KA-07-08-14 (45.7\%), Bakal et al. (2017) reported that protein content values were ranged between $35.0-37.6 \%$ in main crop and
$36.7-38.5 \%$ in double crop growing season. According to the results of a study in Diyarbakir conditions, the protein content ranged between 35.6-38.4\% (Sogut et al., 2005). Compared with the results of some other researchers (Yilmaz and Efe, 1998; Oz and Karasu, 2007; Sincik et al., 2008; Unal and Onder, 2008; Karaaslan, 2011), it can be said that the protein ratios of the genotypes subject to this study are quite promising. 
Table 6. The means of soybean lines and varieties and LSD groups of oil content, oil yield and protein content.

\begin{tabular}{|c|c|c|c|c|c|c|c|}
\hline \multirow{3}{*}{ Genotypes (A) } & \multicolumn{3}{|c|}{ Oil content $(\%)$} & Oil yield kg ha-1 & \multicolumn{3}{|c|}{ Protein content $(\%)$} \\
\hline & \multicolumn{3}{|c|}{ Years (B) } & \multicolumn{4}{|c|}{ Years (B) } \\
\hline & 2015 & 2016 & Mean & Mean of two years & 2015 & 2016 & Mean \\
\hline BDMB-5 & $19.9^{\text {cdef }}$ & $18.7^{f}$ & 19.3 & $655.4^{\text {abcde }}$ & $44.5^{\text {bcde }}$ & $44.6^{\text {cde }}$ & 44.5 \\
\hline BDNA-19 & $20.0^{\text {cdef }}$ & $21.4^{\mathrm{abc}}$ & 20.7 & $662.4^{\text {abcde }}$ & $45.6^{\mathrm{abcd}}$ & $41.4^{\text {fgh }}$ & 43.5 \\
\hline BDNA-20 & $19.7^{\mathrm{ef}}$ & $20.3^{\text {bcde }}$ & 20.0 & $571.49^{\mathrm{gh}}$ & $45.2^{\text {abcde }}$ & $43.1^{\text {cdefg }}$ & 44.2 \\
\hline BDNA-7 & $20.7^{\text {bcdef }}$ & $20.2^{\text {cdef }}$ & 20.4 & $505.6^{\mathrm{h}}$ & $44.0^{\text {bcde }}$ & $44.0^{\text {cdef }}$ & 44.0 \\
\hline BDNA-12 & $20.3^{\text {bcdef }}$ & $20.3^{\text {cde }}$ & 20.3 & $655.8^{\text {abcde }}$ & $43.9^{\text {bcde }}$ & $42.8^{\text {cdefgh }}$ & 43.3 \\
\hline BDNE-14 & $19.9^{\text {def }}$ & $20.5^{\text {bcde }}$ & 20.2 & $627.2^{\text {defg }}$ & $45.1^{\text {abcde }}$ & $43.8^{\text {cdef }}$ & 44.4 \\
\hline BDNA-1 & $21.2^{\mathrm{abcd}}$ & $20.8^{\text {abcde }}$ & 21.0 & $614.2^{\text {efg }}$ & $42.7^{\mathrm{efg}}$ & $42.2^{\text {defgh }}$ & 42.5 \\
\hline BDNA-8 & $20.5^{\text {bcdef }}$ & $21.6^{\mathrm{abc}}$ & 21.1 & $644.3^{\text {bcdefg }}$ & $43.6^{\text {cde }}$ & $41.0^{\mathrm{gh}}$ & 42.3 \\
\hline BDNA-13 & $19.6^{\mathrm{ef}}$ & $21.2^{\mathrm{abcd}}$ & 20.4 & $579.4^{\mathrm{fgh}}$ & $45.8^{\mathrm{abcd}}$ & $43.0^{\text {cdefgh }}$ & 44.4 \\
\hline BDAF-4 & $20.3^{\text {bcdef }}$ & $19.6^{\mathrm{ef}}$ & 19.9 & $622.7^{\text {efg }}$ & $45.0^{\text {abcde }}$ & $53.5^{\mathrm{a}}$ & 49.3 \\
\hline KA-07-05-5 & $20.3^{\text {bcdef }}$ & $22.1^{\mathrm{a}}$ & 21.2 & $661.6^{\text {abcde }}$ & $44.7^{\text {bcde }}$ & $40.3^{\mathrm{h}}$ & 42.5 \\
\hline KA-07-03-9 & $20.1^{\text {bcdef }}$ & $20.6^{\text {bcde }}$ & 20.3 & $701.1^{a b c}$ & $45.1^{\text {abcde }}$ & $43.0^{\text {cdefgh }}$ & 44.0 \\
\hline KA-07-08-12 & $20.1^{\text {bcedf }}$ & $22.2^{\mathrm{a}}$ & 21.2 & $651.3^{\text {abcdef }}$ & $46.4^{\mathrm{ab}}$ & $41.7^{\text {fgh }}$ & 44.1 \\
\hline KA-07-05-9 & $21.6^{\mathrm{ab}}$ & $21.5^{\mathrm{abc}}$ & 21.6 & $671.6^{\mathrm{abcd}}$ & $43.0^{\mathrm{def}}$ & $43.5^{\text {cdefg }}$ & 43.3 \\
\hline KA-07-05-2 & $20.2^{\text {bcdef }}$ & $21.2^{\mathrm{abcd}}$ & 20.7 & $662.6^{\text {abcde }}$ & $44.6^{\text {bcde }}$ & $41.8^{\mathrm{efgh}}$ & 43.2 \\
\hline KA-07-03-5 & $19.5^{\mathrm{ef}}$ & $16.5^{\mathrm{g}}$ & 18.0 & $527.8^{\mathrm{h}}$ & $45.9^{\mathrm{abc}}$ & $48.6^{\mathrm{b}}$ & 47.2 \\
\hline KA-07-08-14 & $19.4^{\mathrm{f}}$ & $20.7^{\text {abcde }}$ & 20.0 & $635.76^{\text {cdefg }}$ & $47.5^{\mathrm{a}}$ & $44.0^{\text {cdef }}$ & 45.7 \\
\hline KA-07-08-15 & $20.0^{\text {cdef }}$ & 20.5 bcde & 20.3 & $579.7^{\text {fgh }}$ & $46.4^{\mathrm{ab}}$ & $44.7^{\mathrm{cd}}$ & 45.5 \\
\hline KA-07-08-9 & $20.5^{\text {bcdef }}$ & $20.8^{\text {abcde }}$ & 20.7 & $530.6^{\mathrm{h}}$ & $46.2^{\mathrm{abc}}$ & $44.5^{\mathrm{cde}}$ & 45.4 \\
\hline KA-07-05-13 & $20.5^{\text {bcdef }}$ & $20.7^{\text {abcde }}$ & 20.6 & $717.5^{a}$ & $44.2^{\text {bcde }}$ & $43.8^{\mathrm{cdef}}$ & 44.0 \\
\hline ARISOY & $22.6^{\mathrm{a}}$ & $21.4^{\text {abcd }}$ & 22.0 & $643.7^{\text {bcdefg }}$ & $40.0^{\mathrm{g}}$ & $43.3^{\text {cdefg }}$ & 41.6 \\
\hline ATAEM 7 & $21.1^{\text {bcde }}$ & $21.2^{\mathrm{abcd}}$ & 21.1 & $724.3^{a}$ & $44.2^{\text {bcde }}$ & $44.1^{\text {cdef }}$ & 44.1 \\
\hline BRAVO & $20.1^{\text {bcdef }}$ & $21.8^{\text {abcd }}$ & 20.9 & $709.7^{\mathrm{ab}}$ & $45.3^{\text {abcde }}$ & $42.0^{\mathrm{defgh}}$ & 43.6 \\
\hline NOVA & $21.4^{\mathrm{abc}}$ & 19.9 def & 20.7 & $661.2^{\text {abcde }}$ & $40.3^{\mathrm{fg}}$ & $45.4^{\mathrm{c}}$ & 42.9 \\
\hline Mean & 20.4 & 20.7 & 20.5 & 634.0 & 44.5 & 43.8 & 44.1 \\
\hline $\operatorname{LSD}\left(\% 1_{\mathrm{AxB}}\right)$ & 0.31 & & 0.46 & 75.6 & 0.57 & & 0.99 \\
\hline
\end{tabular}

\section{ACKNOWLEDGMENT}

We are grateful to the TUBITAK "The Scientific and Technological Research Council of Turkey" funded this research with the project codes of $113 \mathrm{O} 082$ and sub number: $113 \mathrm{O} 086$.

\section{LITERATURE CITED}

Anonymous, 2016. The Meteorological Data for Bornova. Olive Research Institute Meteorological Station.

Arioglu, H.H. 2014. The Oil Crops Growing and Breeding. The Publication of University of Cukurova, Faculty of Agriculture, Faculty number: 220, Book Number: A-70, 204 p. Adana-Turkey.

Arslan, M., N. Isler and S. Caliskan. 2006. Effects of cultivar maturity on growth and yield of double cropped soybean. Acta Agric. Scan. Section B-Soil and Plant 56: 39-46.

Bakal, H., L. Gulluoglu, B. Onat and H. Arioglu. 2017. The Effect of Growing Seasons on Some Agronomic and Quality Characteristics of Soybean Varieties in Mediterranean Region in Turkey. Turk J Field Crops 22(2): 187-196.

Bellaloui, N., H.A. Bruns, H.K. Abbas, A. Mengistu, D.K. Fisher and K.N. Reddy. 2015. Agricultural practices altered soybean seed protein, oil, fatty acids, sugars, and minerals in the Midsouth USA. Front. Plant Sci. V. 6, 31:1-14

Board, J.E. and W. Hall. 1984. Premature flowering in soybean yield reductions at non-optimal planting dates as influenced by temperature and photoperiod. Agron. J. 76: 700-704.

Boerma, H.R. and D.A. Ashley. 1982. Irrigation, row spacing, and genotype effects on late and ultra-late planted soybeans. Agron. J. 78: 995-1002.
Caliskan, S., M. Arslan, I. Uremis and M.E. Caliskan. 2007. The Effects of Row Spacing on Yield and Yield Components of Full Season and Double-Cropped Soybean. Turk J Agric For. 31:147-154

Gaffaroglu Yetkin, S. and H. Arioglu. 2009. Determination of Yield and Important Plant Characteristics of Some Soybean Varieties and Genotypes Grown as a Main Crop in the Cukurova Region. Cukurova University, e-Journal of Institute of Natural and Applied Sciences, 20(1):29-37 (in Turkish with English abstract).

Gulluoglu L., H. Arioglu and C. Kurt. 2011. Adaptability and Stability of New Soybean Cultivars under Double Cropped Conditions of Turkey. African Journal of Agricultural Research Vol. 6(14), pp. 3320-3325. DOI: 10.5897/AJAR10.913

Gulluoglu, L., H. Bakal and H. Arioglu. 2016. The Effects of Twin Row Planting Pattern and Plant Population on Seed Yield and Yield Components of Soybean at Late DoubleCropped Planting in Cukurova Region. Turk J. Field Crops 21:59-65.

Holshouser, D.L. 2010. Days to Soybean Physiological Maturity. Virginia Polytechnic Institute and State University 30091459. Access date: 02.11.2018. Web address: https://pubs.ext.vt.edu/content/dam/pubs ext vt edu/3009/3 009-1459/3009-1459_pdf.pdf

Ilker, E. 2017. Performances of Soybean [Glycine $\max (\mathrm{L}$. Merr.] Advanced Lines Grown in Second Cropping under Mediterranean Climatical Conditions of Western Turkey. Turk J Field Crops 22(1): 104-107.

Kane, M.V., C.C. Steele and L.J. Grabau. 1997. Early maturing soybean cropping system: I. Yield response to planting date. Agron. J. 89, 454-458.

Kang, B-K., H-T. Kim, M-S. Choi, S-C. Koo, J-H. Seo, H-S. Kim, S-O. Shin, H-T. Yun, I-S. Oh, K.P. Kulkarni and J.D. 
Lee. 2017. Genetic and Environmental Variation of First Pod Height in Soybean [Glycine max (L.) Merr.]. Plant Breed. Biotech. https://doi.org/10.9787/PBB.2017.5.1.36.

Karaaslan, D. 2011. Determination of Some Soybean Lines Yield and Quality Components Grown As Second Crop in Diyarbakir Conditions. J. Agric. Fac. HR.U., 2011, 15(3): 37- 44

Mariani, F., S.F. Ren, L. Vargas, H.P. Santos and R.O.B.S. Fontaneli. 2012. Perennial tropical forage grasses establishment simultaneously with soybean and maize in northern of RS state, Brazil. Ciência Rural, v.42, p.14711476

Onat, B., H. Bakal, L. Gulluoglu and H. Arioglu. 2017. The Effects of High Temperature at The Growing Period on Yield and Yield Components of Soybean [Glycine max (L.) Merr] Varieties. Turk J Field Crops 22(2): 178-186.

$\mathrm{Oz}$, M. and A. Karasu. 2007. Investigation of Some Traits of Soybean Seeds Harvested at the Different Growth Stages. Journal of Agricultural Faculty of Uludag University. 21(1):81-91Research Vol. 6(14), pp. 3320-3325. DOI: 10.5897/AJAR10.913

Sincik, M, H.S. Oral, A.T. Goksoy and Z.M. Turan. 2008. Determination of Some Yield and Quality Characters of Different Soybean (Glycine max L. Merr.) Lines under Bursa Ecological Conditions. Journal of Agricultural Faculty of Uludag University. 22(1):55-62

Sogut, T., F. Ozturk and M.G. Temiz. 2005. Comparison of Performance of Soybean (Glycine Max Merr.) Cultivars from Different Maturity Groups Under Main and Second Cropping Systems. 6th Congress of Field Crops of Turkey. $1: 393-398$.
Sousa, L.B., O.T. Hamawaki, C.D. Santos Junior, V.M. Oliveira, A.P.O. Nogueira, F.M. Mundim, R.L. Hamawaki and C.D.L. Hamawaki. 2015. Correlation Between Yield Components in F6 Soybean Progenies Derived from Seven Biparental Crosses. Biosci. J., Uberlândia, 31 (6):1692-1699.

Steel, R.G.D. and Torrie, J.H. 1980. Principles and Procedures of Statistics. A biometrical approach. 2nd edition. McGrawHill, New York, USA, pp. 20-90.

Tugay, E. and N. Atikyilmaz. 2009. Research on Yield, Yield Components and Quality of Some Soybean Genotypes in Aegean Region as Main Crop. Anadolu, J. Of Aari 19 (1) $2009,34-46$

Unal, I. and M. Onder. 2008. Determination of Some Agricultural Characteristics of The Soybean (Glycine max (L.) Merr.) Lines Developed by Hybridization Method. Journal of Selcuk university, Faculty of Agriculture. 22 (45):52-57 (in Turkish).

Whigham, D.K and H.C. Minor. 1978. Agronomic Characteristics and Environmental Stress. Soybean Agronomy, Physiology and Utilization. Geoffrey Norman, A. (Ed.), Academic Press, London. pp. 78-116, 247p.

Yildirim, A. 2017. Determination of Yield and Important Agronomic Traits of Some Soybean Varieties and Lines Grown under Second Crop Condition in The Aegean Region. MSc Thesis. Ege University Graduate School of Natural and Applied Sciences. 69 pages.

Yilmaz, A. H. and L. Efe. 1998. Possibilities of growing of some soybean [Glycine $\max (\mathrm{L}$.) Merill] cultivars as a double crop under Kahramanmaras conditions. Tr. J. of Agriculture and Forestry. 22:135-142 